DOI: $10.15193 /$ zntj/2019/118/277

\author{
MARIAN FLIS, EUGENIUSZ R. GRELA, DARIUSZ GUGAŁA, \\ ALBERT KOŁODZIEJSKI
}

\title{
SKŁAD TUSZKI I PROFIL KWASÓW TŁUSZCZOWYCH MIÉŚNI PIERSIOWYCH SAMCÓW I SAMIC BAŻANTA ŁOWNEGO (PHASIANUS COLCHICUS)
}

\begin{abstract}
Streszczenie
W pracy dokonano oceny wybranych cech anatomiczno-morfologicznych samców i samic bażanta łownego (Phasianus colchicus) pochodzących z dzikiej populacji w rejonie Wyżyny Lubelskiej. Bażanty pozyskano w trakcie polowań w listopadzie 2017 roku w obwodach łowieckich, w których nie były prowadzone zasiedlenia tym gatunkiem. W badaniach wykorzystano 30 ptaków, z czego 10 to samice pozyskane w ośrodku hodowli zwierzyny, a 20 - samce pozyskane w obwodach łowieckich dzierżawionych przez koła łowieckie. Po wypatroszeniu tuszki zważono oraz wypreparowano mięsień piersiowy $(\mathrm{m}$. pectoralis) ptaków. W mięśniu określono zawartość tłuszczu, profil kwasów tłuszczowych oraz wyznaczono indeks aterogenny $(\mathrm{AI})$ i trombogenny $(\mathrm{TI})$, jak również proporcję kwasów hipocholesterolemicznych/hipercholesterolemicznych. Wykazano wyraźny dymorfizm płciowy pod względem masy ciała, a tym samym masy tuszki na korzyść samców. W przypadku ptaków młodych różnica ta wynosiła 274,3 g, a dorosłych - 392,2 g. Również wszystkie oceniane narządy wewnętrzne kur, klasyfikowane jako podroby, miały zdecydowanie mniejszą masę. Najmniejszą wydajnością rzeźną, wynoszącą 70,5\%, charakteryzowały się kury dorosłe, zaś największą - na poziomie 74,2 \% - kury młode. Uzyskane wskaźniki wydajności rzeźnej są zbliżone do rezultatów wydajności rzeźnej bażantów z chowu fermowego, a niewielkie odstępstwa uwarunkowane były wiekiem ptaków oraz ich pochodzeniem. Profil kwasów tłuszczowych tłuszczu bażantów był bardziej zdeterminowany wiekiem ptaków niż płcią. Najbardziej korzystny skład kwasów tłuszczowych oraz wskaźniki atero- i trombogenne stwierdzono w tłuszczu mięśni piersiowych jednorocznych bażantów.
\end{abstract}

Słowa kluczowe: bażant łowny, masa ciała, masa tuszki, podroby, wydajność rzeźna, skład kwasów tłuszczowych

Dr hab. M. Flis, mgr inż. D. Gugała, mgr A. Kołodziejski, Katedra Zoologii i Ekologii Zwierzat, prof. dr hab. E. R. Grela, Instytut Żywienia Zwierząt i Bromatologii, Wydz. Biologii, Nauk o Zwierzętach i Biogospodarki, Uniwersytet Przyrodniczy w Lublinie, ul. Akademicka 13, 20-950 Lublin.

Kontakt:marian.flis@up.lublin.pl 


\section{Wprowadzenie}

Zainteresowanie mięsem zwierząt dzikich sięga dawnych czasów, gdyż w diecie człowieka pojawiło się ok. $3 \mathrm{mln}$ lat temu. Pierwsi ludzie polowali, aby przeżyć, co sprawia, że można ich określić myśliwymi tamtych czasów, a ich organizmy przystosowane były do regularnego spożywania mięsa. Również w epoce lodowcowej mięso upolowanych zwierząt stanowiło podstawową dietę homo sapiens ze względu na brak pokarmu pochodzenia roślinnego lub ograniczoną jego dostępność. Najogólniej można stwierdzić, że dziczyzna jako surowiec mięsny pochodzący z tusz upolowanych zwierząt łownych na polskich stołach gościła niemal od zawsze. Na znaczeniu straciła dopiero ok. 15 - 10 tys. lat p.n.e., kiedy nastąpiło udomowienie zwierząt [17, 19, 24, 25].

Wraz z upływem czasu i z postępem cywilizacyjnym wielokierunkowym przekształceniom uległo środowisko przyrodnicze, a wraz z nim zmieniła się rodzima fauna. Niektóre gatunki wyginęły, natomiast inne znalazły niemal optymalne warunki bytowania. Dodatkowo pojawiły się gatunki obce, dotąd niewystępujące na naszych terenach. Jednym z nich był bażant, nienależący do rodzimych gatunków fauny. Gatunek ten pojawił się jednak w Europie dość wcześnie, bo ponad 2 tys. lat temu. Początkowo jako ptak parkowy, a w późniejszym okresie - gatunek użytkowy. Pierwsze wzmianki o występowaniu bażantów na terenie naszego kraju pochodzą z 1567 roku $[3,10,16]$. Prowadzenie intensywnej hodowli tego gatunku, zwłaszcza po II wojnie światowej, sprawiło, że obecnie występuje on na terenie całego kraju. Posiada status gatunku łownego. Łowieckie pozyskiwanie w powiązaniu z poprawą warunków środowiskowych i zasiedleniami łowisk na poziomie ok. 150 tys. ptaków rocznie przyczynia się do względnej stabilizacji populacji tego gatunku. Wielkość rocznego odstrzału samców na poziomie nieprzekraczającym zasiedleń sprawia, że wśród zwierzyny drobnej, która w ostatnich dziesięcioleciach przeżywa regres liczebności, populacja bażanta jest dość stabilna. Wskazuje to, że gospodarka łowiecka związana z tym gatunkiem prowadzona jest na zasadach zrównoważonego rozwoju, a łowieckie pozyskiwanie tylko części populacji gwarantuje jej dalsze prawidłowe funkcjonowanie. Nie bez znaczenia pozostaje to, że łowieckie pozyskiwanie wyłącznie samców wpływa także stabilizująco na strukturę płciową, co odgrywa istotną rolę w procesach doboru naturalnego tego gatunku $[6,9,11,13,30,32]$. Niemniej jednak spożycie mięsa pochodzącego ze zwierząt dzikich w naszym kraju należy do najniższych w Europie $[14,35]$.

Mięso bażantów cechuje się znacznymi walorami żywieniowymi i prozdrowotnymi. Na podkreślenie zasługują cechy smakowe, wysoka strawność oraz jakość mięsa, o której w dużej mierze decyduje zawartość kwasów tłuszczowych, zwłaszcza wielonienasyconych (PUFA $n-3$ i $n-6$ w odpowiedniej proporcji). Mięso bażantów może zmniejszać ryzyko otyłości i chorób sercowo-naczyniowych. Wiek ptaków i płeć mogą znacznie modyfikować skład tuszki [1, 5, 18, 22], jakość mięsa i profil kwasów tłusz- 
czowych $[4,22,25,26,30,33]$. Dość istotną rolę w tym względzie odgrywa także okres i sposób przechowywania tuszki przed spożyciem, a głównie jej mrożenie [2, 7 , $20]$.

Celem pracy była ocena wybranych cech anatomiczno-morfologicznych kogutów i kur bażantów pozyskanych w środowisku naturalnym oraz określenie masy ciała i wydajności poubojowej, jak również profilu kwasów tłuszczowych tłuszczu mięśni piersiowych w zależności od wieku i płci ptaków.

\section{Material i metody badań}

Materiał do badań stanowiły samce i samice bażanta łownego pozyskane w trakcie polowań w obwodach łowieckich zlokalizowanych w rejonie Wyżyny Lubelskiej. Badania takie są rzadko prowadzone, gdyż zgodnie z obowiązującym prawem samice mogą być odstrzelone wyłącznie na terenach ośrodków hodowli zwierzyny, co znacznie ogranicza dostępność materiału doświadczalnego. Do badań przeznaczono 30 ptaków, z czego 10 stanowiły samice pozyskane w ośrodku hodowli zwierzyny, a 20 samce pozyskane w obwodach łowieckich dzierżawionych przez koła łowieckie. Ptaki zostały odstrzelone zgodnie z obowiązującym prawem. Pozyskanie odbywało się w rejonach, w których wcześniej nie były prowadzone zasiedlenia bażantów, zatem były to ptaki dzikie. Ocenę płci pozyskanych ptaków przeprowadzono z uwzględnieniem cech dymorfizmu płciowego. Na podstawie charakterystycznych cech, tj. barwy cieków, kształtu dzioba, „bursy Fabrycjusza” oraz kształtu i rozwoju ostrogi u samców, dokonano oceny wieku i podzielono osobniki na młode (do pierwszego roku życia) oraz dorosłe (powyżej pierwszego roku życia). Bezpośrednio w terenie dokonywano ważenia każdego osobnika na wadze laboratoryjnej z dokładnością do $1 \mathrm{~g}$. Kolejne ważenie wykonywano $\mathrm{w}$ warunkach laboratoryjnych po dekapitacji oraz usunięciu dolnych partii nóg. Następnie ważono osobniki po oskubaniu oraz tuszki po wypatroszeniu. Dokonywano także pomiaru masy narządów wewnętrznych, tj. serca, wątroby oraz żołądka mięśniowego po oczyszczeniu z treści pokarmowej.

W kolejnym etapie preparowano mięśnie piersiowe (m. pectoralis) ptaków, mielono je w maszynce do mielenia mięsa z siatką o średnicy oczek $2 \mathrm{~mm}$, a uzyskany farsz dokładnie mieszano. Próbki pakowano w folię spożywczą, schładzano i przechowywano w chłodziarce jedną dobę w temp. $4{ }^{\circ} \mathrm{C}$, po czym zamrażano i przechowywano w temp. $-40^{\circ} \mathrm{C}$ do czasu przeprowadzenia analiz laboratoryjnych.

Zawartość tłuszczu surowego oznaczano metodą Folcha i wsp. [15]. W uzyskanym tłuszczu oznaczano profil kwasów tłuszczowych metodą chromatografii gazowej. Estry metylowe kwasów thuszczowych oznaczano w chromatografie gazowym Varian CP 3800 przy następujących warunkach oznaczeń: kolumna kapilarna CP WAX 52CB DF 0,25 UM, $100 \mathrm{~m}$ długości, gaz nośny - hel, przepływ - 1,4 $\mathrm{ml} / \mathrm{min}$, temperatura pracy kolumny $-120^{\circ} \mathrm{C}$ ze stopniowym wzrostem $2{ }^{\circ} \mathrm{C} /$ min do $210{ }^{\circ} \mathrm{C}$, czas oznaczeń 
- 157 min, temperatura dozownika $-160{ }^{\circ} \mathrm{C}$, temperatura detektora $-160{ }^{\circ} \mathrm{C}$, gazy wspomagające - wodór i powietrze.

Obliczano także wskaźniki jakości tłuszczu mięśnia, tj. indeks aterogenny (AI) i trombogenny (TI) według równania podanego przez Ulbrichta i Southgate`a [33]:

$$
\begin{gathered}
\mathrm{AI}=[(4 \times \mathrm{C} 14: 0)+\mathrm{C} 16: 0] /[n-6 \mathrm{PUFA}+n-3 \mathrm{PUFA}+\mathrm{MUFA}] \\
\mathrm{TI}=[\mathrm{C} 14: 0+\mathrm{C} 16: 0+\mathrm{C} 18: 0] /[(0.5 \times \mathrm{MUFA})+(0.5 \times n-6 \mathrm{PUFA})+ \\
(3 \times n-3 \text { PUFA })+n-3 / n-6 \mathrm{PUFA}] .
\end{gathered}
$$

Proporcję kwasów hipocholesterolemicznych/hipercholesterolemicznych $(\mathrm{h} / \mathrm{H})$ wyliczano z równania podanego przez Fernándeza i wsp. [12]:

$\mathrm{h} / \mathrm{H}=(\mathrm{C} 18: 1+\mathrm{C} 18: 2+\mathrm{C} 18: 3+\mathrm{C} 20: 3+\mathrm{C} 20: 4+\mathrm{C} 20: 5+\mathrm{C} 22: 4+\mathrm{C} 22: 5+\mathrm{C} 22: 6) /(\mathrm{C} 14: 0+\mathrm{C} 16: 0)$.

Wskaźniki jakości tłuszczu w postaci indeksów TI (trombogenny) i AI (aterogenny), wyrażające proporcje wybranych kwasów nasyconych do nienasyconych z odpowiednimi mnożnikami regresji wielokrotnej, uważa się za lepsze wskaźniki wartości dietetycznej i zdrowotnej tłuszczu niż stosunek kwasów PUFA/SFA. Przyjmuje się, że im niższa jest ich wartość, tym korzystniejszy jest profil kwasów tłuszczowych pod względem zdrowotnym. Wiąże się to z tym, że nie wszystkie kwasy SFA są hipercholesterolemiczne, a działanie protekcyjne wykazują oprócz kwasów wielonienasyconych (PUFA) także kwasy jednonienasycone (MUFA).

W celu określenia różnic pomiędzy średnimi wartościami analizowanych cech w zależności od wieku i płci bażantów wykonano dwuczynnikową analizę wariancji. Do zweryfikowania istotności różnic pomiędzy wartościami średnimi zastosowano test Tukeya $(\mathrm{p} \leq 0,05)$ dla danych nieortogonalnych w programie Statistica 10.0.

\section{Wyniki i dyskusja}

Wystąpiły znaczące, statystycznie istotne różnice $(\mathrm{p} \leq 0,05)$ masy ciała i masy tuszy pomiędzy osobnikami młodymi i dorosłymi zarówno w grupie samców, jak i samic (tab. 1). W obydwu grupach wiekowych różnice pod względem masy ciała i masy tuszki oraz średnich wartości cech mierzonych podczas postępowania po odstrzale (masa tuszki bez głowy i dolnych partii nóg, masa tuszki po oskubaniu) były znaczące i statystycznie istotne $(\mathrm{p} \leq 0,05)$. Średnia masa ciała samców bażantów, bez względu na wiek, była o 354,7 g większa niż samic. Również średnia masa tuszki samców była większa o $259,9 \mathrm{~g}$ w porównaniu z samicami. W obydwu przypadkach różnice były statystycznie istotne $(\mathrm{p} \leq 0,05)$.

Masa narządów wewnętrznych również wykazywała znaczne zróżnicowanie ze względu na wiek i płeć ptaków (tab. 2). Zarówno młode, jak i dorosłe samce charakteryzowały się większą masą serca - koguty miały średnio o $2,7 \mathrm{~g}$ większe serca w porównaniu z kurami. Różnice te były statystycznie istotne $(\mathrm{p} \leq 0,05)$. 
Tabela 1. Masa ciała i masa tuszki $[\mathrm{g}]$ na kolejnych etapach postępowania $\mathrm{z}$ upolowanymi bażantami Table 1. Body weight and weight of carcass $[\mathrm{g}]$ at successive stages of proceeding with hunted pheasants

\begin{tabular}{|c|c|c|c|c|c|c|c|c|c|}
\hline \multirow{2}{*}{\multicolumn{2}{|c|}{$\begin{array}{l}\text { Wiek zwierząt } \\
\text { Age animals }\end{array}$}} & \multicolumn{2}{|c|}{$\begin{array}{l}\text { Masa ciała } \\
\text { Body weight }\end{array}$} & \multicolumn{2}{|c|}{$\begin{array}{l}\text { Masa tuszki bez głowy } \\
\text { i dolnych partii nóg } \\
\text { Weight of carcass } \\
\text { without head and lower } \\
\text { parts of legs }\end{array}$} & \multicolumn{2}{|c|}{$\begin{array}{c}\text { Masa tuszki po } \\
\text { oskubaniu } \\
\text { Carcass weight after } \\
\text { plucking }\end{array}$} & \multicolumn{2}{|c|}{$\begin{array}{c}\text { Masa tuszki } \\
\text { Carcass weight }\end{array}$} \\
\hline & & $\begin{array}{l}\text { Samce } \\
\text { Male }\end{array}$ & $\begin{array}{l}\text { Samice } \\
\text { Female }\end{array}$ & $\begin{array}{l}\text { Samce } \\
\text { Male }\end{array}$ & $\begin{array}{l}\text { Samice } \\
\text { Female }\end{array}$ & $\begin{array}{l}\text { Samce } \\
\text { Male }\end{array}$ & $\begin{array}{l}\text { Samice } \\
\text { Female }\end{array}$ & $\begin{array}{l}\text { Samce } \\
\text { Male }\end{array}$ & $\begin{array}{l}\text { Samice } \\
\text { Female }\end{array}$ \\
\hline \multirow{3}{*}{$\begin{array}{l}\text { Młode } \\
\text { Young }\end{array}$} & $\mathrm{n}$ & 8 & 5 & 8 & 5 & 8 & 5 & 8 & 5 \\
\hline & $\overline{\mathrm{X}}$ & $1218,3^{\mathrm{a}, \mathrm{x}}$ & $944,0^{b, x}$ & $1168,3^{\mathrm{a}, \mathrm{x}}$ & $908,6^{b, x}$ & $1020,0^{\mathrm{a}, \mathrm{x}}$ & $803,8^{b, x}$ & $860,0^{\mathrm{a}, \mathrm{x}}$ & $700,0^{b, x}$ \\
\hline & SD & 73,3 & 40,3 & 78,6 & 38,5 & 54,0 & 44,4 & 70,4 & 28,5 \\
\hline \multirow{3}{*}{$\begin{array}{l}\text { Dorosłe } \\
\text { Adult }\end{array}$} & $\mathrm{n}$ & 12 & 5 & 12 & 5 & 12 & 5 & 12 & 5 \\
\hline & $\overline{\mathrm{X}}$ & $1432,2^{\mathrm{a}, \mathrm{y}}$ & $1040,0^{\mathrm{a}, \mathrm{y}}$ & $1375^{\mathrm{a}, \mathrm{y}}$ & $1003,1^{b, y}$ & $1217^{\mathrm{a}, \mathrm{y}}$ & $854,6^{b, x}$ & $1054,6^{\mathrm{a}, \mathrm{y}}$ & $733,6^{b, x}$ \\
\hline & SD & 99,5 & 41,8 & 98,4 & 40,6 & 82,1 & 72,5 & 87,1 & 76,6 \\
\hline \multirow{3}{*}{$\begin{array}{l}\text { Ogółem } \\
\text { Total }\end{array}$} & $\mathrm{n}$ & 20 & 10 & 20 & 10 & 20 & 10 & 20 & 10 \\
\hline & $\overline{\mathrm{X}}$ & $1346,7^{\mathrm{a}}$ & $992,0^{b}$ & $1292,7^{\mathrm{a}}$ & $956,2^{b}$ & $1138,7^{\mathrm{a}}$ & $829,2^{\mathrm{b}}$ & $976,7^{\mathrm{a}}$ & $716,8^{b}$ \\
\hline & SD & 139,1 & 63,73 & 137,0 & 62,5 & 122,3 & 62,7 & 125,9 & 56,7 \\
\hline
\end{tabular}

Objaśnienia / Explanatory notes:

$\overline{\mathrm{X}}$ - wartość średnia / mean value; SD - odchylenie standardowe / standard deviation; $\mathrm{a}, \mathrm{b}$ - średnie masy ciała i tuszki pomiędzy samcami i samicami w grupach wiekowych oraz ogółem różnią się statystycznie istotnie $(\mathrm{p} \leq 0,05) /$ mean weights of body and carcass differ statistically significantly $(\mathrm{p} \leq 0.05)$ between males and females in age groups and in total; $\mathrm{x}, \mathrm{y}$ - średnie masy ciała $\mathrm{i}$ tuszki pomiędzy osobnikami młodymi i dorosłymi w grupie samców i samic różnią się statystycznie istotnie $(p \leq 0,05) /$ mean weights of body and carcass differ statistically significantly $(\mathrm{p} \leq 0.05)$ between young and adult specimens in the group of males and females.

Średnia masa serca samic młodych i dorosłych różniła się o $0,2 \mathrm{~g}$ i była statystycznie nieistotna $(\mathrm{p}>0,05)$. Dorosłe samce oraz samice miały większe wątroby niż młode ptaki. Różnice masy tych narządów wynosiły odpowiednio: 1,4 g i 2,8 g, ale nie były one statystycznie istotne ( $\mathrm{p}>0,05)$. Samce miały wątroby średnio o 4,3 g cięższe niż samice. Podobnie, jak w przypadku innych narządów, samce charakteryzowała większa $(\mathrm{p} \leq 0,05)$ masa żołądka mięśniowego w porównaniu $\mathrm{z}$ kurami. $\mathrm{Z}$ uwagi na wiek większą masę żołądków miały osobniki młode i dorosłe samice. W obydwu przypadkach różnice te okazały się jednak statystycznie nieistotne $(\mathrm{p}>0,05)$. Niezależnie od wieku, we wszystkich przypadkach samce miały większą $(\mathrm{p} \leq 0,05)$ masę ocenianych narządów wewnętrznych w porównaniu z samicami. 
Tabela 2. Masa narządów wewnętrznych [g] kogutów i kur bażantów

Table 2. Mass of internal organs [g] cocks and pheasants hens

\begin{tabular}{|c|c|c|c|c|c|c|c|}
\hline \multirow{2}{*}{\multicolumn{2}{|c|}{$\begin{array}{l}\text { Wiek zwierząt } \\
\text { Age animals }\end{array}$}} & \multicolumn{2}{|c|}{ Serce / Heart } & \multicolumn{2}{|c|}{ "Wątroba / Liver } & \multicolumn{2}{|c|}{ Żołądek / Stomach } \\
\hline & & \multirow{2}{*}{$\begin{array}{c}\begin{array}{c}\text { Samce } \\
\text { Male }\end{array} \\
8 \\
\end{array}$} & \multirow{2}{*}{$\begin{array}{c}\text { Samice } \\
\text { Female } \\
5\end{array}$} & \multirow{2}{*}{$\begin{array}{c}\begin{array}{c}\text { Samce } \\
\text { Male }\end{array} \\
8\end{array}$} & \multirow{2}{*}{$\begin{array}{c}\begin{array}{c}\text { Samice } \\
\text { Female }\end{array} \\
5\end{array}$} & \multirow{2}{*}{$\begin{array}{c}\begin{array}{c}\text { Samce } \\
\text { Male }\end{array} \\
8\end{array}$} & \multirow{2}{*}{$\begin{array}{c}\text { Samice } \\
\text { Female } \\
5\end{array}$} \\
\hline \multirow{3}{*}{$\begin{array}{l}\text { Młode } \\
\text { Young }\end{array}$} & $\mathrm{n}$ & & & & & & \\
\hline & $\overline{\mathrm{X}}$ & $5,8^{\mathrm{a}, \mathrm{x}}$ & $4,2^{b, x}$ & $19,7^{\mathrm{a}, \mathrm{x}}$ & $14,8^{\mathrm{a}, \mathrm{x}}$ & $20,0^{\mathrm{a}, \mathrm{x}}$ & $13,4^{\mathrm{b}, \mathrm{x}}$ \\
\hline & $\mathrm{SD}$ & 0,4 & 0,4 & 4,1 & 3,3 & 3,7 & 1,34 \\
\hline \multirow{3}{*}{$\begin{array}{l}\text { Dorosłe } \\
\text { Adult }\end{array}$} & $\mathrm{n}$ & 12 & 5 & 12 & 5 & 12 & 5 \\
\hline & $\overline{\mathrm{X}}$ & $7,2^{\mathrm{a}, \mathrm{y}}$ & $4,4^{\mathrm{a}, \mathrm{x}}$ & $21,1^{\mathrm{a}, \mathrm{x}}$ & $17,6^{\mathrm{a}, \mathrm{x}}$ & $18,4^{\mathrm{a}, \mathrm{x}}$ & $14,6^{\mathrm{b}, \mathrm{x}}$ \\
\hline & SD & 1,2 & 0,4 & 4,4 & 2,3 & 3,7 & 1,5 \\
\hline \multirow{3}{*}{$\begin{array}{l}\text { Ogółem } \\
\text { Total }\end{array}$} & $\mathrm{n}$ & 20 & 10 & 20 & 10 & 20 & 10 \\
\hline & $\overline{\mathrm{X}}$ & $6,7^{\mathrm{a}}$ & $4,3^{b}$ & $20,5^{\mathrm{a}}$ & $16,2^{\mathrm{b}}$ & $19,1^{\mathrm{a}}$ & $14,0^{\mathrm{b}}$ \\
\hline & SD & 1,8 & 0,5 & 4,2 & 3,0 & 3,7 & 1,5 \\
\hline
\end{tabular}

Objaśnienia / Explanatory notes:

$\overline{\mathrm{X}}$ - wartość średnia / mean value; SD - odchylenie standardowe / standard deviation; a, b - średnie masy narządów wewnętrznych pomiędzy samcami i samicami w grupach wiekowych i ogółem różnią się statystycznie istotnie $(\mathrm{p} \leq 0,05) /$ mean weights of internal organs differ statistically significantly $(\mathrm{p} \leq 0.05)$ between males and females in age groups and in general; x, y - średnie masy narządów wewnętrznych pomiędzy osobnikami młodymi i dorosłymi w grupie samców i samic różnią się statystycznie istotnie $(\mathrm{p} \leq 0,05) /$ mean weights of internal organs differ statistically significantly $(\mathrm{p} \leq 0.05)$ between young and adults in group of males and females $(\mathrm{p} \leq 0.05)$.

Wydajność rzeźna bażantów była zależna od płci i wieku ptaków. W przypadku młodych samców udział tuszki stanowił 70,6 \% masy ciała. Pozostałą część stanowiły części niejadalne oraz jadalne narządy wewnętrzne (podroby), których udział stanowił 3,7 \% masy ciała (rys. 1). Dorosłe samce charakteryzowała większa wydajność rzeźna (rys. 2). Udział tuszki w masie ciała stanowił 73,6 \%, udział części niejadalnych $23,1 \%$, a podrobów - 3,3 \%. Z kolei wydajność rzeźna młodych samic była największa i wynosiła 74,2 \% (rys. 3), zaś samic dorosłych - najmniejsza (70,5 \%) i zbliżona do młodych samców (rys. 4).

Przedstawione wyniki masy ciała samców i samic bażantów są znacznie wyższe niż 16-tygodniowych ptaków utrzymywanych w warunkach hodowli fermowej. Mieczkowska i wsp. [31] podali masę tuszki samców bażantów fermowych 16tygodniowych na poziomie $870,9 \mathrm{~g}$, zaś samic $-628,9 \mathrm{~g}$. Z kolei wydajność rzeźna samic i samców w tych samych badaniach była mniejsza w porównaniu z ptakami dzikimi objętych niniejszymi badaniami i wynosiła 69,6 \%, zaś udział podrobów w tuszce ptaków dzikich, zwłaszcza samic, był mniejszy. Z kolei Kokoszyński i wsp. [21] w badaniach przyrostów masy ciała bażantów w chowie zamkniętym uzyskali średnią masę ciała kogutów 16-tygodniowych na poziomie 1240 g, a 20-tygodniowych $1355 \mathrm{~g}$. Masa ciała kur w tych samych badaniach wynosiła odpowiednio: 956 i $998 \mathrm{~g}$. 
Wydajność rzeźna w wieku 20 tygodni kształtowała się na poziomie ok. $70 \%$. W badaniach wpływu wieku i płci na cechy użytkowe tuszek bażantów fermowych masa ciała 12-tygodniowych samców wynosiła 937 g, 16-tygodniowych - 1198 g,

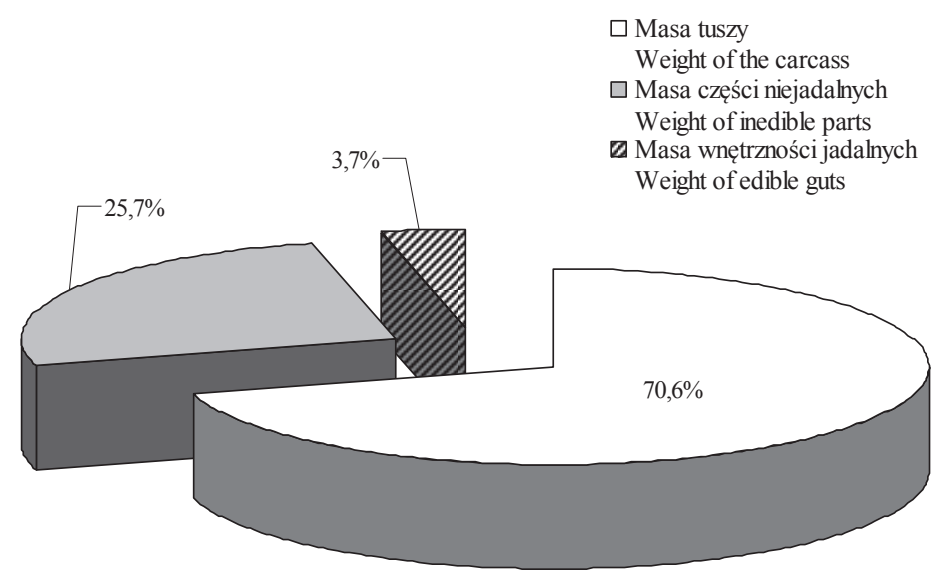

Rys. 1. Wydajność rzeźna młodych samców bażantów

Fig. 1 Slaughter productivity of young male pheasants

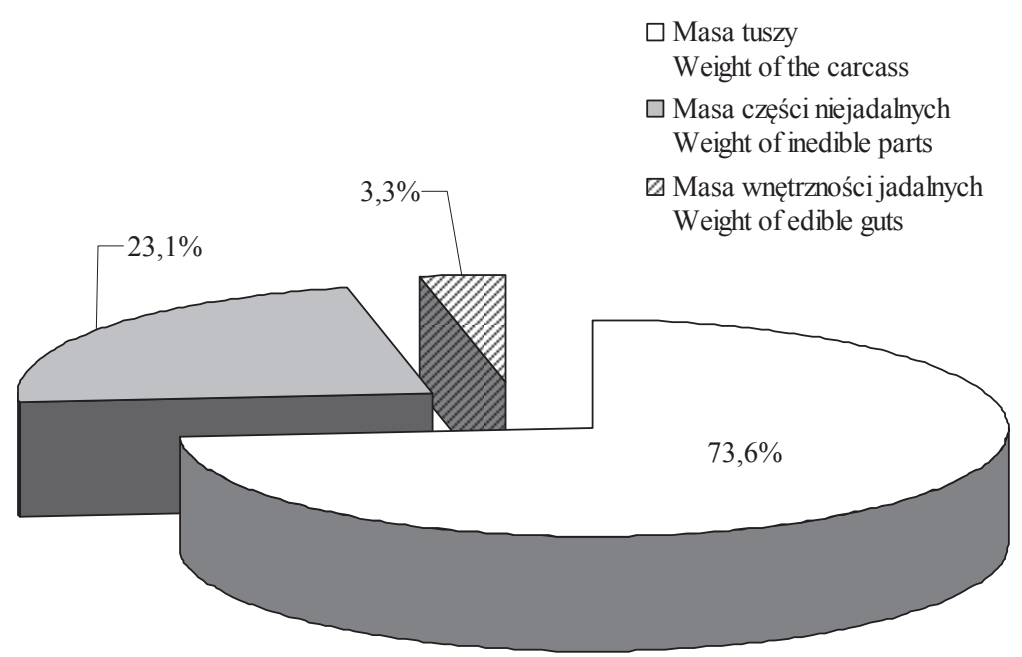

Rys. 2. Wydajność rzeźna dorosłych samców bażantów

Fig. 2. Slaughter productivity of adult male pheasants 


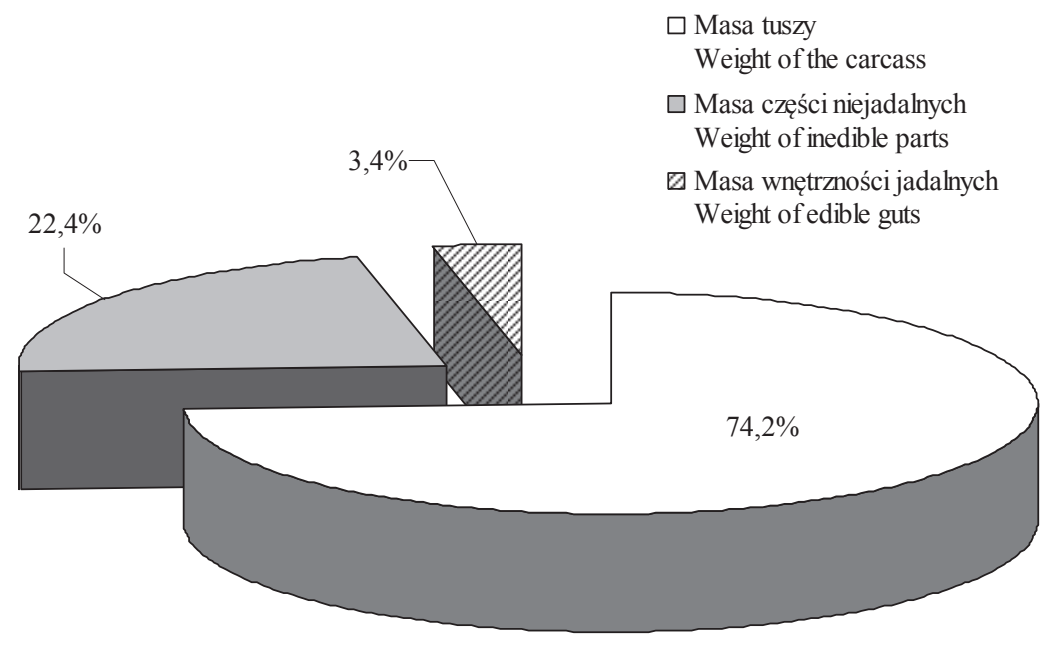

Rys. 3. Wydajność rzeźna młodych samic bażantów

Fig. 3. Slaughter productivity of young female pheasants

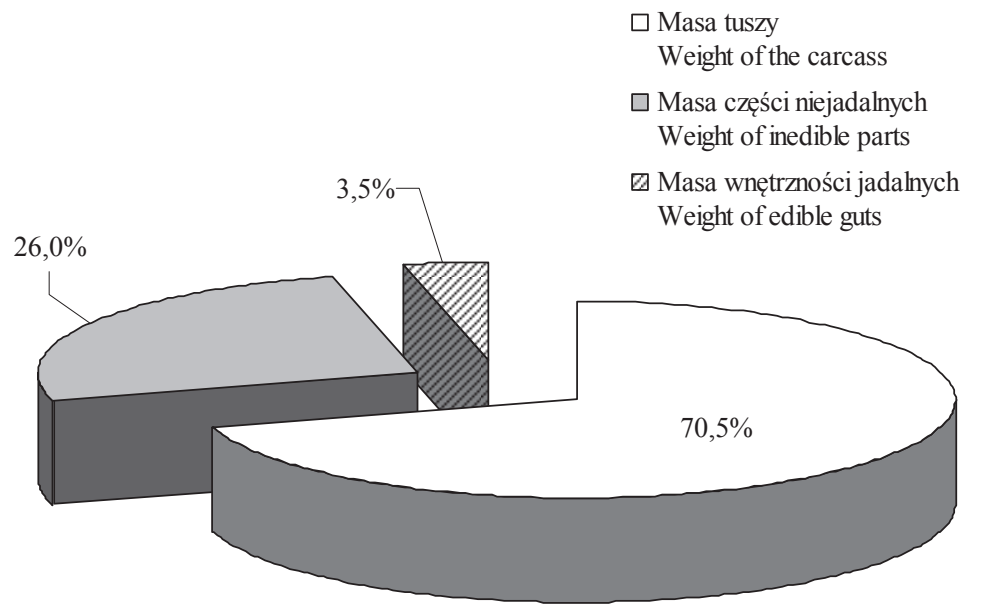

Rys. 4. Wydajność rzeźna dorosłych samic bażantów

Fig. 4. Slaughtering productivity of adult female pheasants

a 20-tygodniowych - $1247 \mathrm{~g}$. Masa ciała kur w tych samych okresach kształtowa się na poziomie odpowiednio: 710,874 i $888 \mathrm{~g}$ [1]. W tych samych badaniach wydajność rzeźna 16- i 20-tygodniowych kogutów była zbliżona i wynosiła ok. 73 \% [1]. Wydajność rzeźna 16-tygodniowych bażantów fermowych podana przez Łukasiewicz i wsp. [29] wynosiła w przypadku kogutów 71,9 \%, a kur - 73,5 \%. W tych samych bada- 
niach masa ciała samców kształtowała się na poziomie 1226,2 g, a samic - 1124,9 g. Biesiada-Drzazga i wsp. [4] prowadzili badania wydajności rzeźnej bażantów fermowych w użytkowaniu mięsnym i wykazali, że ciała kogutów w 20. tygodniu życia osiągnęły masę $1039 \mathrm{~g}$, a kur - na poziomie $813 \mathrm{~g}$. Masa serca kogutów była mniejsza, a kur - osiągnęła taką samą wartość jak w niniejszych badaniach. Z kolei masa wątroby kur i kogutów była zbliżona. Wyniki masy ciała i wydajności rzeźnej bażantów pochodzących $\mathrm{z}$ chowu fermowego w badaniach innych autorów [1, 4, 21, 29] różnią się od wyników odnoszących się do ptaków dziko żyjących, uzyskanych w badaniach własnych. Różnice te mogą być warunkowane wiekiem ptaków, jak również zupełnie odmiennym spektrum czynników związanych ze środowiskami, w których przebywają. Jednocześnie należy podkreślić, że w literaturze przedmiotu brak jest szczegółowych danych dotyczących opisanych cech bażantów dzikich, a zwłaszcza samic, co uwarunkowane jest brakiem możliwości pozyskania materiału doświadczalnego.

Badania porównawcze cech anatomiczno-morfologicznych samców bażantów dzikich i pochodzących z chowu zamkniętego prowadzone w 2010 roku w rejonie Wyżyny Lubelskiej umożliwiły wykazanie wyraźnej przewagi masy ciała bażantów pochodzących z hodowli zamkniętej nad dzikimi [3]. Uzyskane wyniki wskazują, że masa ciała kogutów dzikich jest obecnie większa niż tych w 2010 roku oraz zdecydowanie mniejsza w porównaniu $\mathrm{z}$ bażantami fermowymi pochodzącymi z tamtego okresu. Również masa serca i wątroby obecnie jest zdecydowanie mniejsza w porównaniu zarówno z kogutami dzikimi, jak i fermowymi w 2010 roku [3].

W składzie kwasów tłuszczowych mięśnia piersiowego uwidocznił się wpływ zarówno wieku, jak i dymorfizmu płciowego (tab. 3). W tłuszczu mięśnia piersiowego dorosłych samic stwierdzono mniejszy udział kwasu palmitynoleinowego $(16: 1, n-9)$, wakcenowego $(18: 1, n-7)$, linolenowego $(18: 3, n-3)$ i arachidonowego $(20: 4, n-6)$, a większy - kwasu stearynowego (18:0), oleinowego (18:1, n-9) i linolowego (18:2, n-6) niż w tłuszczu mięśnia młodych ptaków. Znacząco odmienne relacje odnotowano w tłuszczu samców, gdyż osobniki dorosłe cechowały się większym udziałem kwasu stearynowego (18:0), linolowego (18:2, $n$ - $)$, a istotnie mniejszym - kwasu oleinowego (18:1, n-9) i arachidonowego (20:4, $n$ - $)$ w thuszczu mięśnia piersiowego (tab. 3). Największy udział kwasów nasyconych stwierdzono w tłuszczu dorosłych samców, jednonienasyconych - samców młodych, a wielonienasyconych - samic niezależnie od wieku. Najmniej korzystne indeksy AI, TI i h/H stwierdzono w thuszczu mięśnia piersiowego samców dorosłych, a najbardziej korzystną proporcją kwasów PUFA $n-6 / n-3$ cechował się tłuszcz mięśniowy bażantów młodych, przede wszystkim samic, lecz różnica wartości średnich nie była statystycznie istotna $(\mathrm{p}>0,05)$. 
Tabela 3. Profil kwasów tłuszczowych [\%] tłuszczu mięśnia piersiowego bażantów w zależności od płci i wieku

Table 3. Profile of fatty acids [\%] of breast muscle fat of pheasants depending on sex and age

\begin{tabular}{|c|c|c|c|c|c|c|c|}
\hline \multirow{2}{*}{$\begin{array}{c}\text { Kwasy } \\
\text { thuszczowe } \\
\text { Fatty acids }\end{array}$} & \multicolumn{3}{|c|}{ Samice / Females } & \multicolumn{3}{|c|}{ Samce / Males } & \multirow[b]{2}{*}{ SEM } \\
\hline & $\begin{array}{l}\text { Młode } \\
\text { Youngs }\end{array}$ & $\begin{array}{l}\text { Dorosłe } \\
\text { Adults }\end{array}$ & $\overline{\mathrm{X}}$ & $\begin{array}{l}\text { Młode } \\
\text { Youngs }\end{array}$ & $\begin{array}{l}\text { Dorosłe } \\
\text { Adults }\end{array}$ & $\overline{\mathrm{X}}$ & \\
\hline C 12:0 & 0,03 & 0,05 & 0,04 & 0,06 & 0,04 & 0,05 & 0,001 \\
\hline C 14:0 & 0,74 & 0,69 & 0,72 & 0,67 & 0,73 & 0,70 & 0,06 \\
\hline C 16:0 & 23,52 & 23,23 & $23,37^{x}$ & 23,63 & 24,40 & $24,02^{y}$ & 0,69 \\
\hline C $16: 1 n-9$ & $4,75^{\mathrm{a}}$ & $4,02^{\mathrm{b}}$ & $4,39^{x}$ & 3,77 & 3,58 & $3,67^{y}$ & 0,23 \\
\hline C 17:0 & 0,11 & 0,18 & 0,14 & 0,15 & 0,16 & 0,16 & 0,05 \\
\hline C $17: 1$ & 0,02 & 0,03 & 0,03 & 0,04 & 0,02 & 0,03 & 0,001 \\
\hline C 18:0 & 8,64 & 9,15 & $8,89^{\mathrm{x}}$ & $9,50^{\mathrm{b}}$ & $10,38^{\mathrm{a}}$ & $9,94^{y}$ & 0,42 \\
\hline C $18: 1 n-9$ & 35,52 & 36,20 & $35,86^{\mathrm{x}}$ & $37,88^{\mathrm{a}}$ & $35,49^{\mathrm{b}}$ & $36,68^{y}$ & 1,04 \\
\hline C $18: 1 n-7$ & $3,88^{\mathrm{a}}$ & $3,31^{\mathrm{b}}$ & 3,55 & $3,95^{\mathrm{a}}$ & $3,44^{\mathrm{b}}$ & 3,69 & 0,21 \\
\hline C $18: 2 n-6$ & $16,58^{\mathrm{b}}$ & $17,79^{\mathrm{a}}$ & $17,19^{x}$ & $15,38^{\mathrm{b}}$ & $16,66^{\mathrm{a}}$ & $16,02^{y}$ & 0,54 \\
\hline C $18: 3 n-3$ & $1,13^{\mathrm{a}}$ & $0,87^{\mathrm{b}}$ & 1,00 & 0,98 & 0,91 & 0,95 & 0,19 \\
\hline C 20:0 & 0,14 & 0,11 & 0,13 & 0,10 & 0,10 & 0,10 & 0,02 \\
\hline C $20: 1 n-9$ & 0,26 & 0,26 & 0,26 & 0,20 & 0,20 & 0,20 & 0,07 \\
\hline C 20:2n-6 & 0,17 & 0,13 & 0,15 & 0,19 & 0,12 & 0,15 & 0,08 \\
\hline C $20: 4 n-6$ & $3,62^{\mathrm{a}}$ & $3,27^{b}$ & 3,45 & $3,52^{\mathrm{a}}$ & $3,10^{\mathrm{b}}$ & 3,31 & 0,24 \\
\hline SFA & 33,09 & 33,21 & $33,10^{x}$ & $32,95^{\mathrm{b}}$ & $35,64^{\mathrm{a}}$ & $34,29^{y}$ & 1,39 \\
\hline MUFA & 44,74 & 44,14 & 44,44 & $46,16^{\mathrm{a}}$ & $43,08^{\mathrm{b}}$ & 44,62 & 1,23 \\
\hline PUFA & 21,50 & 22,07 & $21,78^{x}$ & 20,07 & 20,79 & $20,43^{y}$ & 0,81 \\
\hline PUFA $n-3$ & $1,13^{\mathrm{a}}$ & $0,87^{\mathrm{b}}$ & 1,00 & 0,98 & 0,91 & 0,95 & 0,11 \\
\hline PUFA $n-6$ & 20,37 & 21,20 & $20,79^{x}$ & 19,08 & $19,87^{\mathrm{y}}$ & 19,48 & 1,15 \\
\hline$n-3 / n-6$ & 0,06 & 0,04 & 0,05 & 0,05 & 0,05 & 0,05 & 0,01 \\
\hline $\mathrm{AI}$ & 0,40 & 0,39 & 0,40 & 0,38 & 0,43 & 0,41 & 0,07 \\
\hline TI & 0,91 & 0,94 & 0,93 & $0,92^{\mathrm{b}}$ & $1,04^{\mathrm{a}}$ & 0,98 & 0,11 \\
\hline $\mathrm{h} / \mathrm{H}$ & 2,50 & 2,57 & 2,53 & $2,66^{\mathrm{a}}$ & $2,37^{b}$ & 2,52 & 0,14 \\
\hline$n-6 / n-3$ & $18,03^{\mathrm{b}}$ & $24,37^{\mathrm{a}}$ & $21,20^{x}$ & $19,47^{\mathrm{b}}$ & $21,83^{\mathrm{a}}$ & $20,65^{\mathrm{y}}$ & 1,06 \\
\hline
\end{tabular}

Objaśnienia / Explanatory notes:

$\overline{\mathrm{X}}$ - wartość średnia / mean value; a, b - średni udział kwasów tłuszczowych pomiędzy grupami wiekowymi samców lub samic różni się statystycznie istotnie $(\mathrm{p} \leq 0,05)$ / mean share of fatty acids differ statistically significantly $(\mathrm{p} \leq 0.05)$ among age groups for males and females; $\mathrm{x}, \mathrm{y}$ - średni udział kwasów thuszczowych pomiędzy samcami i samicami różni się statystycznie istotnie $(\mathrm{p} \leq 0,05) /$ mean share of fatty acids differ statistically significantly $(\mathrm{p} \leq 0.05)$ between males and females.

Skład kwasów tłuszczowych mięśnia piersiowego bażantów kształtował się na poziomie podanym przez innych autorów [28, 29, 31]. Generalnie thuszcz mięśnia piersiowego cechował się większym udziałem kwasów tłuszczowych nasyconych, głównie stearynowego, a mniejszym kwasów PUFA, zwłaszcza linolowego. Nieco odmienne 
wyniki przedstawiono w pracy Mieczkowskiej i wsp. [31], którzy odnotowali większy udział kwasu stearynowego, a mniejszy - linolenowego w mięśniach piersiowych samic niż samców, lecz badania te prowadzone były na osobnikach pochodzących z chowu fermowego. Z kolei Kotowicz i wsp. [26] podali, że występują różnice ilości kwasów tłuszczowych w mięśniach piersiowych samców i samic bażantów pochodzących z chowu fermowego. Ulbricht i Southgate [33] uważają indeksy aterogenny (AI) i trombogenny (TI), wyrażające proporcję wybranych kwasów tłuszczowych nasyconych do nienasyconych, za lepsze wskaźniki aterogeniczności i trombogeniczności niż stosunek kwasów PUFA/SFA. Przyjmuje się, że im niższa jest ich wartość, tym profil kwasów tłuszczowych jest korzystniejszy pod względem zdrowotnym dla człowieka. Wiąże się to $\mathrm{z}$ tym, że nie wszystkie kwasy SFA są hipercholesterolemiczne, a działanie protekcyjne oprócz kwasów wielonienasyconych (PUFA) wykazują także kwasy jednonienasycone (MUFA). Najbardziej korzystne wskaźniki AI i TI oraz stosunek PUFA $n-6 / n-3$ stwierdzono w tłuszczu mięśnia piersiowego bażantów młodych. Uzyskane wyniki badań wskazują na wysoką wartość żywieniową i prozdrowotną mięsa bażantów. Stosunek PUFA/SFA w tłuszczu samic na poziomie 0,66, a samców 0,60 , jak również stosunek $n-6 / n-3$ wynoszący w przypadku samic 21,20 , a samców 20,65 jest potwierdzeniem walorów prozdrowotnych tego rodzaju mięsa $[8,34]$.

\section{Wnioski}

1. Wyniki przeprowadzonych badań potwierdzają występowanie wyraźnego dymorfizmu płciowego bażantów dzikich pod względem masy ciała i narządów wewnętrznych, jak również zróżnicowanie profilu kwasów tłuszczowych. Dymorfizm płciowy nie rzutował jednak na wydajność rzeźną. Wyraźna przewaga masy ciała samców wskazuje na większe możliwości wykorzystania ich tuszek do celów kulinarnych.

2. Przedstawione wyniki dotyczące cech anatomiczno-morfologicznych samców i samic bażantów dzikich wskazują, w odniesieniu do danych literaturowych, na zdecydowanie mniejszą masę ciała oraz wydajność rzeźną ptaków dzikich niezależnie od płci w porównaniu z bażantami utrzymywanymi w warunkach fermowych. Uwarunkowane jest to mniejszym otłuszczeniem oraz nieznacznie mniejszą masą mięśni.

3. Profil kwasów thuszczowych tłuszczu bażantów był bardziej zdeterminowany wiekiem ptaków niż płcią. Najbardziej korzystny skład kwasów tłuszczowych oraz wskaźniki atero- i trombogenne odnotowano w tłuszczu mięśnia piersiowego jednorocznych bażantów.

4. Uzyskane wyniki potwierdzają bardzo wysokie walory prozdrowotne mięsa bażantów, które stanowić może interesujący składnik diety ludzi. Powinno to znaleźć odzwierciedlenie w promocji tego rodzaju mięsa i jego wyrobów, a tym samym 
zachęcać konsumentów do jego spożycia. Warto byłoby też określić wpływ zróżnicowanej diety bażantów pod względem składników mineralnych w połączeniach organicznych na zawartość tych składników w mięsie bażantów.

\section{Literatura}

[1] Adamski M., Kuźniacka J.: The effect of age and sex on slaughter traits of pheasants (Phasianus colchicus L.). Anim. Sci. Pap. Rep., 2006, 24, 11-18.

[2] Attia Y.A., Al-Harthi M.A., Korish M.A., Shiboob M.M.: Fatty acid and cholesterol profiles, hypocholesterolemic, atherogenic, and thrombogenic indices of broiler meat in the retail market. Lipids Health Dis., 2017, 16, 40-47.

[3] Beeger S., Wójcik M., Flis M., Marecki M., Pyrkosz R., Dziedzic R.: Cechy anatomomorfologiczne bażantów z hodowli fermowej i wolno żyjących. Med. Weter., 2017, 73 (6), 370-374.

[4] Biesiada-Drzazga B., Socha S., Janocha A., Banaszkiewicz T., Koncerewicz A.: Ocena wartości rzeźnej i jakości mięsa bażantów łownych (Phasianus colchicus). Żywność. Nauka. Technologia. Jakość, 2011, 1 (74), 79-86.

[5] Bogosavljevic-Boskovic S., Kurcubic V., Petrovic D.M., Radovic V.: The effect of sex and rearing system on carcass composition and cut yields of broiler chickens. Czech J. Anim. Sci., 2006, 51 (1), 31-38.

[6] Bresiński W., Kamieniarz R., Panek M.: Gospodarowanie podstawowymi gatunkami zwierzyny drobnej. Poradnik zagospodarowania łowisk polnych i gospodarowania podstawowymi gatunkami zwierzyny drobnej. Wyd. Łowiec Polski, Warszawa 2003, ss. 120-135.

[7] Chwastowska-Siwiecka I., Kaliniewicz J., Kondratowicz J., Skiepko J.: Wpływ czasu zamrażalniczego przechowywania i metody rozmrażania na profil kwasów tłuszczowych tłuszczu śródmięśniowego mięsa króliczego. Żywność. Nauka. Technologia. Jakość, 2014, 4 (95), 122-135.

[8] Deng Y., Padilla-Zakour O., Zhao Y., Tao S.: Influences of high hydrostatic pressure, microwave heating, and boiling on chemical compositions, antinutritional factors, fatty acids, in vitro protein digestibility, and microstructure of buckwheat. Food Bioprocess Technol., 2015, 8 (11), 2235-2245.

[9] Dziedzic R.: Introdukcje wybranych gatunków zwierzyny drobnej. W: Nauka łowiectwu. Cz. 1. Kryzys zwierzyny drobnej i sposoby przeciwdziałania. Wyd. Samorząd Województwa Mazowieckiego, Warszawa 2007, ss. 48-50.

[10] Dzięciołowski R., Kowalina E., Plata Z., Sikorski J.: Bażant - hodowla i użytkowanie. PWRiL, Warszawa 1971, ss. 5-126.

[11] Dzięciołowski R.: Idea zrównoważonego łowiectwa na świecie. Ann. Warsaw Univ. Life Sci. SGGW, Anim. Sci., 2011, 50, 3-10.

[12] Fernández M., Ordóñez J.A., Cambero I., Santos C., Pin C., Hoz L.: Fatty acid compositions of selected varieties of Spanish dry ham related to their nutritional implications. Food Chem., 2007, 101, 107-112.

[13] Flis M.: Efektywność wsiedleń bażantów z hodowli wolierowych na Wyżynie Lubelskiej. Przegl. Hod., 2012, 10-12, 23-25.

[14] Flis M., Magdziak K., Rataj B.: Społeczne i ekonomiczne uwarunkowania spożycia dziczyzny. Przegl. Leś., 2017, 8 (314/XXVII), 12-14.

[15] Folch J., Less M., Stanley G.H.: A simple method for the isolation and purification of total lipids from animal tissues. J. Biol. Chem., 1957, 226, 497-509.

[16] Glutz V., Blotzheim U.N., Bauer K., Bezzel E.: Handbuch der Vögel Mitteleuropas 5. Akademische Verlagsgesellschaft, Frankfurt am Main 1973, pp. 322-372. 
[17] Higman B.W.: Historia żywności. Wyd. Aletheia, Warszawa 2012.

[18] Hofbauer P., Smulders F.J.M., Vodnansky M., Paulsen P., El-Ghareeb W.R.: A note on mest quality traits of pheasants (Phasianus colchicus). Europ. J. Wildl. Res., 2010, 56 (5), 809-813.

[19] Kasprzyk A.: Mięso w diecie człowieka - historia, teraźniejszość i przyszłość. W: Produkcja zwierzęca w warunkach zrównoważonego rolnictwa. Mat. LXXVIII Zjazdu Nauk. Polskiego Towarzystwa Zootechnicznego, Kraków 2013, ss. 133-145.

[20] Klebaniuk R., Patkowski K., Kowalczuk-Vasilev E.: Wpływ przechowywania mięsa jagnięcego na jego jakość fizyko-chemiczną. Bromat. Chem. Toksykol., 2011, XLIV (1), 76-81.

[21] Kokoszyński D., Bernacki Z., Cisowska A.: Growth and development of young game pheasant (Phasianus colchicus). Archiv Tierzucht., 2011, 54, 83-92.

[22] Kokoszyński D., Bernacki Z., Duszyński L.: Body conformation, carcass composition and physicochemical and sensory properties of meat from pheasants of different origin. Czech J. Anim. Sci., 2012, 57 (3), 115-124.

[23] Kokoszyński, D., Bernacki Z., Pieczewski W.: Carcass composition and quality of meat from game pheasants ( $P$. colchicus) depending on age and sex. Europ. Poult. Sci., 2014, 78. DOI: 10.1399/eps.2014.16.

[24] Konarzewski M.: Na początku był głód. Ewolucja ludzkiej diety. PIW, Warszawa 2005.

[25] Konarzewski M.: Od paleolitu do syntetycznego hamburgera: ewolucyjna historia zwyczajów żywieniowych człowieka. W: Ewolucja na talerzu, czyli wczoraj, dziś i jutro żywienia człowieka. Red. J. Gawęcki. Wyd. UP, Poznań 2015, ss. 9-23.

[26] Kotowicz M., Lachowicz K., Lisiecki S., Szczygielski M., Zych A.: Characteristics of common pheasant (Phasianus colchicus) meat. Arch. Geflügelk., 2012, 4 (76), 270-276.

[27] Kuźniacka J., Adamski M., Bernacki Z.: Effect of age and sex of pheasants (Phasianus colchicus L.) on selected physical properties and chemical composition of meat. Ann. Anim. Sci., 2007, 1 (7), 4553.

[28] Litwińczuk A., Dziedzic R., Litwińczuk Z., Grodzicki T., Kędzierska-Matysek M.: Comparison of nutritional value of meat of wild and farm pheasants. Fleischwirtschaft Inter., 2007, 2 (22), 50-52.

[29] Łukasiewicz M., Michalczuk M., Głogowski R., Balcerak M., Popczyk B.: Carcass efficiency and fatty acid content of farmer pheasant (Phasianus colchicus) meat. Ann. Warsaw Univ. Life Sci. SGGW, Anim. Sci., 2011, 49, 199-203.

[30] Mazaraki M.: Łowiectwo w Polsce. Krajowa Agencja Wydawnicza, Kraków 1993, ss. 151-166.

[31] Mieczkowska A., Kokoszyński D., Wasilewski R., Bernacki Z.: Skład tuszki i jakość mięsa bażantów zwyczajnych (Phasianus colchicus colchicus) w zależności od płci ptaków. Żywność. Nauka. Technologia. Jakość, 2015, 3 (100), 95-106.

[32] Mróz E.: Bażanty. Oficyna Wyd. „HOZA”, Warszawa 2003, ss. 5-128.

[33] Ulbricht T.L.V., Southgate D.A.T.: Coronary disease seven dietary factors. Lancet, 1991, 338, 985992.

[34] Wood J.D., Richardson R.I., Nute G.R., Fisher A.V., Campo M.M., Kasapidou E., Sheard P.R., Enser M.: Effects of fatty acids on meat quality: A review. Meat Sci., 2004, 66 (1), 21-32.

[35] Żmijewski T., Cierach M., Kwiatkowska A.: Wartość użytkowa tusz zwierząt łownych. Rocz. Inst. Przem. Mięs. Tłuszcz., 2007, SLV (2), 17-23. 


\title{
CARCASS COMPOSITION AND FATTY ACID PROFILE OF PECTORAL MUSCLE OF MALE AND FEMALE PHEASANTS (PHASIANUS COLCHICUS)
}

\author{
S u m m a ry
}

In the research study, there were assessed some selected anatomical and morphological features of male and female pheasants (Phasianus colchicus) from a wildlife population in the region of the Lublin Upland. The pheasants were acquired during hunts in hunting areas in November 2017, where no reintroduction of this species was carried out. Thirty birds were utilized in the research study, of which 10 were females recruited at a game breeding centre and 20 males were acquired in hunting districts leased by hunting clubs. The carcasses were eviscerated, weighed and the breast muscle ( $m$. pectoralis) of the birds was dissected. In the muscle, there were determined the fat content and the fatty acid profile as were the atherogenic (AI) and thrombogenic (TI) index and the ratio of hypocholesterolemic/hypercholesterolemic acids. A marked sexual dimorphism was shown in the body weight and thus in the carcass weight in favour of the males. In the case of young birds, the difference was $274.3 \mathrm{~g}$ and in the case of the adults $392.2 \mathrm{~g}$. Also, as for the hens, the weight of all their internal organs classified as offals was significantly lower. The adult hens were characterised by the lowest slaughter efficiency equalling $70.5 \%$, whereas the young hens by the highest equalling $74.2 \%$. The slaughterhouse performance indicators obtained were similar to those obtained for the pheasants bred in poultry farms; small deviations were conditioned by the age and origin of the birds. The profile of fatty acid in the fat of pheasants was determined more by the age of birds than by their sex. The most beneficial composition of fatty acids and the most beneficial atheroand thrombogenic indices were found in the fat in pectoral muscles of one-year-old pheasants.

Key words: pheasant, body weight, carcass weight, offals, slaughter yield, fatty acid composition 